\title{
Gambaran Pelaksanaan Program Adiwiyata di SD Pertiwi Kota Makassar
}

\author{
Jusman, Muhammad Ardi, Bakhrani Rauf \\ PKLH PPS Universitas Negeri Makassar, Sulawesi Selatan, Indonesia \\ anjusoppeng@gmail.com
}

C 2018 - UEJ Program Studi Pendidikan Kependudukan dan Lingkungan Hidup

Universitas Negeri Makassar. Ini adalah artikel dengan akses terbuka dibawah Licensi CC BY-NC-4.0 (http:/creativecommons.org/licenses/by-nc/4.0)

\begin{abstract}
.
Pelestarian lingkungan hidup merupakan kebutuhan yang tidak dapat ditunda lagi dan bukan hanya tanggung jawab negara saja, melainkan tanggung jawab setiap insan di bumi. Upaya pemerintah untuk mewujudkan kehidupan adil dan makmur bagi rakyatnya, harus disertai dengan tindakan pencegahan kerusakan lingkungan. Berbagai program pembangunan berkelanjutan dilakukan sebagai bagian perlindungan kualitas lingkungan. Salah satu program pembangunan berkelanjutan di bidang lingkungan, adalah pendidikan lingkungan hidup yang dimulai pada tingkat SD, SMP, SMA/SMK. Artikel ini membahas gambaran pelaksanaan program Adiwiyata. Program adiwiyata yaitu sekolah yang peduli terhadap lingkungan sekitarnya, yang meliputi sekolah bersih, sehat, indah serta lingkungan berwawasan global yang mengharapkan semua orang ataupun warga sekolah dapat sadar akan betapa pentingnya lingkungan sekitar. Maka dari itu sekolah yang menjalankan program adiwiyata memiliki kebijakan pengintegrasi pendidikan lingkungan hidup, seperti pada sekolah dasar pertiwi di kota makassar yang menjadi penelitian ini.

Keywords: pendidikan, lingkungan hidup, program adiwiyata, sekolah
\end{abstract}

\section{PENDAHULUAN}

Pelestarian lingkungan hidup merupakan kebutuhan yang tidak dapat ditunda lagi dan bukan hanya tanggung jawab negara saja, melainkan tanggung jawab setiap insan di bumi. Setiap manusia harus melakukan usaha untuk menyelamatkan lingkungan hidup di sekitarnya sesuai dengan kapasitasnya masing-masing. Sekecil apa pun usaha yang dilakukan sangat besar manfaatnya bagi terwujudnya bumi yang layak huni bagi generasi anak cucu dikemudian hari (Muhammad, 2015).

Upaya pemerintah untuk mewujudkan kehidupan adil dan makmur bagi rakyatnya, harus disertai dengan tindakan pencegahan kerusakan lingkungan. Berbagai program pembangunan berkelanjutan dilakukan sebagai bagian perlindungan kualitas lingkungan. Salah satu program pembangunan berkelanjutan di bidang lingkungan, adalah pendidikan lingkungan hidup yang dimulai pada tingkat SD, SMP, SMA/SMK.

Pendidikan lingkungan tidak hanya memberikan pengetahuan tentang lingkungan tetapi juga meningkatkan kesadaran terhadap lingkungan dan kepeduliannya dengan kondisi lingkungan (Hamzah, 2013). Melalui pendidikan lingkungan individu akan dapat memahami pentingnya lingkungan, dan bagaimana keterkaitan lingkungan dengan masalah ekonomi, sosial, budaya serta pembangunan. Oleh karena, jika pembangunan dipahami sebagai usaha sadar untuk membentuk sikap dan perilaku manusia, maka pendidikan lingkungan harus dipahami sebagai upaya untuk membawa individu ke arah perubahan gaya hidup dan perilaku yang ramah lingkungan. Pendidikan lingkungan diarahkan untuk mengembangkan pemahaman dan motivasi serta keterampilan yang diwarnai dengan kepedulian terhadap penggunaan dan konservasi sumber daya alam secara wajar (Pertiwi, 2015).

Salah satu kebijakan pendidikan lingkungan di Indonesia adalah Program adiwiyata yang merupakan amanah UU No.23 Tahun 1997 tentang Pengelolaan Lingkungan Hidup dan UU No. 32 Tahun 2009 tentang Perlindungan dan Pengelolaan Lingkungan Hidup, tepat pasal 65 butir 2, setiap orang berhak mendapatkan pendidikan lingkungan hidup, akses informasi, akses partisipasi, dan akses keadilan dalam memenuhi hak atas lingkungan hidup yang baik dan sehat. Tindak lanjut dari UU No.32 Tahun 2009 adalah Peraturan Menteri Lingkungan Hidup No. 02 Tahun 2009 tentang pedoman pelaksanaan program adiwiyata, dan diperbaharui dengan Peraturan Menteri Lingkungan Hidup No. 05 Tahun 2013 tentang pedoman pelaksanaan program adiwiyata. Program adiwiyata diharapkan dapat mengubah pola pikir siswa terhadap pentingnya keseimbangan lingkungan, sehingga siswa akan 
menjadi calon pemimpin yang mengerti dan melaksanakan konsep pembangunan berkelanjutan (Dewi,2019). Artikel ini akan membahas mengenai gambaran program adiwiyata Sekolah Dasar Pertiwi yang menjadi penelitian ini di kota makassar.

\section{KEBIJAKAN SEKOLAH BERWAWASAN LINGKUNGAN}

Subjek pertama dalam kegiatan ini adalah kebijakan berwawasan lingkungan, kebijakan tersebut diwujudkan dengan penyusunan rencana kegiatan sekolah yang mencakup visi, misi, dan tujuan sekolah. Hasil observasi ditemukan pada SD Pertiwi bahwa visi, misi dan tujuan yaitu:

\section{Penyusunan Visi, Misi, dan Tujuan Sekolah}

(1) Visi

Mewujudkan lingkungan sekolah yang berbudaya peduli lingkungan untuk unggul di bidang IPTEK dan berwawasan IMTAQ.

(2) Misi

(a) Menciptakan lingkungan sekolah yang sehat, hijau, asri dan nyaman.

(b) Menerapkan pembelajaran Aktif, Inovatif, Kreatif dan menyenangkan (PAIKEM) berbasis lingkungan sekolah.

(c) Mendaur ulang barang bekas menjadi benda/alat yang berguna.

(d) Melaksanakan pembelajaran yang berbasis lingkungan dengan situasi yang kondusif yang mengedepankan pelayanan kepada para peserta didik dengan pendekatan yang sesuai perkembangan zaman (Konseptual).

(e) Menciptakan situasi yang bernuansa lingkungan dalam meningkatkan IMTAQ dalam proses pembelajaran.

(f) Melaksanakan pendidikan dengan menciptakan kecerdasan ganda, yang mengedepankan.

(g) Menggalang kerjasama dengan seluruh masyarakat, orang tua dalam mewujudkan budaya peduli lingkungan dan aktifitas pembelajaran disekolah.

(3) Tujuan

(a) Menjadi siswa beriman dan bertakwa kepada Tuhan Yang Maha Esa serta mempunyai akhlak mulia.

(b) Menjadi siswa yang sehat jasmani dan rohani serta dapat mengembangkan daya kreatifitasnya.

(c) Memiliki nilai-nilai kejujuran, tanggung jawab, hormat dan kasih.

(d) Menciptakan lingkungan yang sehat, asri hijau dan nyaman.

(e) Memberikan pengetahuan kepada anak didik tentang pentingnya memelihara lingkungan sekitar.

(f) Melatih siswa untuk berfikir kreatif memanfaatkan barang-barang bekas untuk dimanfaatkan (Daur Ulang).

(g) Memiliki integritas dalam berpikir, bertutur kata dan berperilaku.

(h) Memiliki dasar-dasar pengetahuan, kemampuan dan keterampilan untuk melanjutkan pada jenjang yang lebih tinggi.

(i) Menjadi siswa kreatif, terampil bekerja dan disiplin dalam mengembangkan diri secara terus menerus.

(j) Memiliki kemampuan daya saing dalam kompetisi akademik maupun non-akademik.

Pada visi SD Pertiwi nampak bahwa tujuan pembelajaran lingkungan adalah terciptanya lingkungan sekolah dan budaya peduli lingkungan. Sehingga secara umum target dari pelaksanaan Adiwiyata di sekolah ini pada aspek fisik dan aspek manusia. Untuk pencapaian fisik lingkungan sekolah maka sekolah menyusun misi dan tujuan pengembangan partisipasi aktif warga belajar melalui pendidikan lingkungan.

Sebagai wujud aktivitas penerapan visi, misi dan tujuan pada SD Pertiwi terdapat berbagai aktivitas. Hasil wawancara dengan kepala sekolah.

"Pada visi sekolah kami menekankan agar budaya peduli lingkungan dapat dikembangkan oleh siswa dan semua unsur sekolah. Kemudian dalam misi sekolah ini setiap warga sekolah diwajibkan menjaga dan menciptakan lingkungan hidup yang sehat, hijau, asri dan nyaman. Sedangkan dalam melakukan upaya meningkatkan pengetahuan lingkungan bagi siswa telah tercantum di dalam tujuan sekolah" (Hasliah, 15 Agustus 2018, SD Pertiwi). 
Visi dan Misi disosialisasikan pada guru dan siswa melalui berbagai cara. Hasil wawancara dengan kepala sekolah mengenai sosialisasi visi, misi, dan tujuan sekolah dilakukan dengan berbagai cara seperti yang diuraikan sebagai berikut:

"Penyampaian visi, misi dan tujuan sekolah melalui pemajangan dibeberapa tempat strategis disekitar sekolah melalui pemanjangan dibeberapa tempat strategis disekitar sekolah pada amanat saat upacaradan sosialisasi pada guru kelas" (Hasliah, 15 Agustus 2018, SD Pertiwi).

Pemahaman siswa tentang pelaksanaan visi, misi dan tujuan sekolah yang berwawasan lingkungan dikaji dengan aktivitas wawancara disajikan pada setiap sekolah. Hasil wawancara disajikan sebagai berikut:

"tidak tau". (Nrl, 15 Agustus 2018, SD Pertiwi).

"tau". (Ay, 15 Agustus 2018, SD Pertiwi).

"tau saat amanah kalau upacara biasa dijelaskan". (Ar, 15 Agustus 2018, SD Pertiwi).

Namun beberapa siswa menyatakan pengetahuan mereka mengenai sekolahnya adalah sekolah Adiwiyata. Selanjutnya peneliti bertanya pada siswa mengenai apa yang diketahui siswa mengenai sekolah Adiwiyata. Berikut jawaban beberapa siswa dalam wawancara sebagai berikut.

"Sekolah yang peduli dengan lingkungan". (Nrl, 15 Agustus 2018, SD Pertiwi).

"Ada kegiatan daur ulangnya". (Ay, 15 Agustus 2018, SD Pertiwi).

"Sekolah yang banyak tanamannya" (Ar, 15 Agustus 2018, SD Pertiwi).

Berdasarkan hasil wawancara dengan siswa tentang kebijakan berwawasan lingkungan maka diperoleh gambaran bahwa sosialisasi program adiwiyata pada SD Pertiwi belum efektif pada tingkat siswa. Implementasi program secara faktual nampak pada lingkungan yang bersih disebabkan oleh kemampuan guru mengatur dan mengaktifkan partisipasi siswa.

Efektivitas pelaksanaan program adiwiyata dicapai dengan dukungan partisipasi siswa. Semua warga sekolah termasuk siswa harus ikut serta dalam kegiatan pemeliharaan dan pengelolaan lingkungan hidup (Satya,2017). Partisipasi siswa dalam pelaksanaan program sekolah Adiwiyata di SD Pertiwi terbentuk akibat adanya motivasi dari guru berupa perintah dan aturan sekolah.

Kebijakan berwawasan lingkungan juga ditandai dengan alokasi anggaran dana yang disediakan untuk pelaksanaan program adiwiyata. Perumusan anggaran tersbut dituangkan dalam rencana kegiatan dan anggaran sekolah (RKAS).

\section{Rencana Kegiatan dan Anggaran Sekolah}

Rencana Kegiatan dan Anggaran Sekolah (RKAS) disusun dengan tujuan: (1) Memberikan arah yang jelas program sekolah; (2) Merencanakan kegiatan-kegiatan sekolah di masa yang akan datang; (3) Menjamin tercapainya integrasi, sinkronisasi, dan sinergi pendanaan pada kegiatan- kegiatan sekolah; (4) Menjamin keterkaitan dan konsistensi antara perencanaan, penganggaran, pelaksanaan dan pengawasan; (5) Mengoptimalkan partisipasi warga sekolah dan masyarakat dan hal dukungan financial; (6) Menjamin tercapainya penggunaan sumber dana secara efisien, efektif, berkeadilan, dan berkesinambungan.

Penyediaan anggaran sekolah yang mendukung pelaksanaan adiwiyata juga nampak pada SD Pertiwi. Hasil wawancara dengan Kepala Sekolah sebagai berikut.

"sekolah ini melibatkan orang tua, alumni, komite sekolah, LSM, media dunia usaha/industri, konsultan, instansi pemerintah daerah, sekolah lain dll. Keterlibatan industri dan dunia usaha yaitu sebagai narasumber dalam beberapa pertemuan pada pelajaran yang mengintegrasikan lingkungan hidup. Selain itu secara khusus sekolah ini mengembangkan sarana fisik setiap tahunnya”. (Hasliah, 15 Agustus 2018, SD Pertiwi).

Hasil penelusuran dokumen pada SD Pertiwi yang menggambarkan sarana fisik melalui penganggaran pada pelaksanaan program Adiwiyata yaitu pada tahun 2016 sekolah menyediakan anggaran untuk pengadaan Hidroponik dan Kebun Sekolah sebesar Rp. 8.000.000,00, selanjutnya tahun 2017 sekolah menyediakan anggaran untuk pembuatan Kolam Ikan dan pemeliharan Pagar Taman serta Kebun Sekolah sebesar Rp. 17.000.000,00, serta pada tahun 2018 sekolah meneyediakan anggaran untuk IPAL dan Green House sebesar Rp. 15.000.000,00. 
Hasil wawancara di atas menunjukkan bahwa RKAS memuat anggaran yang dialokasikan untuk program yang berkaitan dengan lingkungan. Dana RKAS berasal dari dana BOS. Apabila dijumlahkan anggaran untuk lingkungan mencapai $20 \%$ dari keseluruhan anggaran dalam RKAS.

Berdasarkan uraian di atas, SD Pertiwi mengalokasikan anggaran sekolah untuk memfasilitasi sarana pendidikan lingkungan. Hidriponik dan Kebun Sekolah memungkinkan berlatih dalam budidaya tanaman sayuran. Kolam Ikan memungkinkan siswa berlatih dalam memelihara ikan. IPAL atau instalasi pembuangan air limbah memberikan pengetahuan siswa tentang teknik pengolahan air limbah yang tepat. Sedangkan Green House menjadi media pembelajaran bagi siswa dalam materi budidaya tanaman hias. Uraian diatas menunjukkan bahwa SD Pertiwi mengembangkan sarana pendidikan lingkungan untuk peningkatan pengetahuan, sikap dan keterampilan siswa.

\section{Keteladanan}

Penerapan visi, misi dan tujuan sekolah serta dengan pengalokasian anggaran memerlukan tindakan oleh guru untuk memberikan keteladan paduli lingkungan. Berbagai cara telah dilakukan oleh bapak/ibu guru agar siswa teladan pada peduli lingkungan, berikut wawancara kepada bapak/ibu guru mengenai hal tersebut pada SD Pertiwi.

"Siswa ikut melaksanakan kegiatan membersihkan, serta menerapkan kegiatan LISA (lihat sampah ambil)". (Kasau, 15 Agustus 2018, SD Pertiwi)

"Siswa ikut dalam kegiatan membersihkan lingkungan melalui LISA (lihat sampah ambil)". (Hj. Nursiah, 15 Agustus 2018, SD Pertiwi)

Hasil wawancara menunjukkan bahwa guru memberi keteladanan dan mengaktifkan partisipasi siswa dalam kebersihan sekolah. Hal ini menunjukkan bahwa perilaku siswa dalam pemeliharaan kebersihan sekolah tercipta dengan adanya keteladanan guru. Keteladan tidak bisa ditularkan lewat lisan tetapi dengan perbuatan (Halimatussakdiah, 2018). Oleh karena, guru harus turut berperan aktif dalam pemeliharan lingkungan sekolah dalam bentuk aktivitas nyata.

\section{Kebiasaan Rutin}

Setelah melakukan observasi dan wawancara kepada bapak/ibu guru dari keempat sekolah ditemukan bahwa kebiasaan rutin yang dilakukan warga sekolah dalam menjaga dan memelihara lingkungan sebagai berikut.

"Kebiasaan rutin membersihkan kelas sebelum pelajaran dimulai disetiap kelas terdapat piket yang bertanggung jawab dalam menjaga kebersihan sepanjang hari. Selain itu terdapat piket pengawas kebersihan lingkungan sekolah". (Kasau, 15 Agustus 2018, SD Pertiwi).

"Semua siswa diajarkan bertanggung jawab terhadap kebersihan kelas. Guru mengajarkan siswa membuang sampah pada tempatnya, memungut jika melihat sampah serta membersihkan kelas sehingga siswa memliki kebiasaan membersihkan atau menghindari adanya sampah". (Hj. Nursiah, 15 Agustus 2018, SD Pertiwi).

Manajemen sekolah menerapkan kebersihan sebagai kebiasaan rutin pada siswa dan guru. Pada tingkat tingkat siswa terdapat pengaturan kebersihan kelas dengan jadwal rutin yang dibuat dalam bentuk pembagian tugas siswa dari senin sampai sabtu untuk membersihkan kelas, adapun pada tingkat sekolah terdapat guru piket yang bertugas mengawasi dan mengarahkan warga sekolah untuk menjaga kebersihan lingkungan sekolah.

\section{Kendala yang Dihadapi}

Kendala yang dihadapi pihak sekolah dalam mengembangkan sikap siswa untuk peduli lingkungan serta dalam penyusunan rencana kegiatan dan anggaran sekolah.

"Adanya sikap acuh tak acuh dari siswa. Piket kebersihan yang diatur secara kelompok biasanya hanya dijalankan oleh satu atau dua orang siswa". (Hasliah, 15 Agustus 2018, SD Pertiwi).

"Kendala utama yang dihadapi adalah siswa yang tidak peduli dengan kegiatan memberihkan kelas". (Hj. Nursiah, 15 Agustus 2018, SD Pertiwi) 
Hasil penelitian menunjukkan bahwa pelaksaaan adiwiyata di SD Pertiwi mengalami berbagai kendala dalam menumbuhkan kepedulian siswa, terbatasanya anggaran untuk pembelajaran lingkungan dan ketidakmampuan mengajarkan pendidikan lingkungan hidup.

\section{PELAKSANAAN KURIKULUM BERBASIS LINGKUNGAN}

Perencanaan Pembelajaran

Pelaksanaan kurikulum berbasis lingkungan dilakukan dengan menyusun indikator, RPP dan silabus pembelajaran. Hasil wawancara dengan kepala sekolah tentang pelaksanaan kurikulum sebagai berikut.

"Penyusunan RPP dan perangkat lainnya pada umumnya dipahami oleh semua guru. Namun yang sulit adalah syarat megintegrasikan pembelajaran lingkungan pada materi pembelajaran. Olehnya guru-guru biasanya berdiskudi untuk menyelesaikan RPP”. (Hasliah, 15 Agustus 2018,SD Pertiwi).

Pelaksanaan kurikulum pada semua sekolah mensyaratkan adanya integrasi materi lingkungan hidup pada mata pelajaran. Hal terbukti pada penyusunan RPP dan Silabus. Namun kesulitannya adalah ketidakmampuan guru menyusun RPP secara sempurna yaitu kesulitan menghubungkan materi pelajaran degan materi lingkungan hidup.

\section{Pelaksanaan Pembelajaran}

Sistem pembelajaran (pendekatan dan metode) yang dilakukan guru dalam melaksanakan pembelajaran berbasis lingkungan

"Berbagai metode pelibatan siswa dalam kebersihan lngkungan sekolah. Sebagai contoh guru olahraga menyuruh siswa untuk memungut sampah yang berserakan di sekitar sekolah setelah pelajaran olahraga usai. Guru juga mengajarakan siswa untuk memilah sampah organik dan anorganik dan buang pada tempat yang sesuai”. (Kasau, 15 Agustus 2018, SD Pertiwi).

"Pada mata pelajaran IPA guru mengajarkan teknik memelihara tanaman dengan: mempraktekkan cara memelihara tanaman, mempraktekkan cara menanam tanaman di pot bunga, mengidentifikasi tanaman yang berupa bibit dan tanaman yang sudah remaja". (Hj. Nursiah, 15 Agustus 2018, SD Pertiwi).

Pelaksanaan pembelajaran berbasis lingkungan diwujudkan dengan pembelajaran eduktif menanamkan kedisiplinan siswa sejak dini tentang pengolahan sampah dan kebiasaan menjaga lingkungan.

\section{Kendala yang Dihadapi}

Kendala yang dihadapi sekolah dalam pelaksanaan kurikulum berbasis lingkungan pada SD Pertiwi sebagai berikut:

"Sejauh ini tidak ada kendala karena pendekatan pada siswa sangat aktif dalam pembelajaran baik dalam maupun luar kelas”. (Kasau, 15 Agustus 2018, SD Pertiwi).

"Guru tidak memiliki kendala, karena dalam pelaksanaan kurikulum berbasis lingkungan siswa sangat aktif baik dalam pemberian materi maupun praktek". (Hj. Nursiah, 15 Agustus2018, SD Pertiwi).

Berdasarkan hasil wawancara yang dilakukan pada pelaksanaan kurikulum berbasis lingkungan, dalam aplikasinya tidak ditemukan kendala berarti karena guru mampu mengimbangi pemberian materi yang telah dikelola sebelumnya sehingga tercipta suasana kelas yang kondusif.

\section{KEGIATAN LINGKUNGAN BERBASIS PARTISIPASTIF}

Pemeliharaan Gedung dan Lingkungan

Strategi pemeliharaan gedung dan lingkungan sekolah yang dilaksanakan di sekolah SD Pertiwi, adapun hasil wawancara yaitu. 
"Guru memerintahkan kepada siswa untuk memelihara kebersihan gedung dan lingkungan sekolah seperti adanya peringatan tidak mencoret dinding, adanya peringatan tidak membuang sampah sembarangan”. (Hasliah, 15 Agustus, 2018, SD Pertiwi).

Hasil wawancara yang dilakukan dengan guru mengenai pelaksanaan kegiatan pemeliharaan Gedung yang berarti siswa ikut berperan dan memberikan partisipasi dengan kebiasaan sekolah dan diimbangi dengan peraturan tidak tertulis yang berlaku tentang kebiasaan yang akan menjadi rutinitas.

\section{Kegiatan Ekstrakurikuler}

Kegiatan ekstrakurikuler yang dilaksanakan di sekolah yang salah satu tujuannya mengembangkan perilaku peduli lingkungan.

"Adanya kegiatan ekskul seperti UKS dan dokter kecil ysng merupakan kegiatan pendukung pengembangan perilaku peduli lingkungan siswa".(Hasliah, 15 Agustus 2018, SD Pertiwi).

Berdasarkan hasil wawancara, pihak sekolah memberikan kesempatan bagi siswa untuk mengikuti kegiatan ekstrakurikuler berupa Kegiatan UKS dan dokter kecil untuk mengembangkan potensi, minat bakat, dan hobi anak terhadap perilaku peduli lingkungan hidup. Kegiatan ini dapat memperdalam dan memperluas pengetahuan keterampilan mengenai program Adiwiyata.

\section{Kreativitas dan Inovasi}

Kegiatan kreativitas dan inovasi warga sekolah dalam upaya pengelolaan lingkungan hidup seperti daur ulang sampah, pemanfaatan dan pengolahan air, karya seni, hemat energi dan energi alternatif.

"Kegiatan siswa membuat tanaman hidroponik, berbagai macam hiasan, kerajinan dan lain-lain dari daur ulang barang bekas merupakan bentuk kreativitas dan inovasi”. (Kasau, 15 Agustus 2018, SD Pertiwi).

"Guru mengadakan lomba daur ulang antar kelas yang dapat membangkitkan kreativitas siswa". (Hj. Nursiah, 15 Agustus 2018, SD Pertiwi).

Berdasarkan hasil wawancara yang dilakukan kengiatan lingkungan berbasis partisipatif berupa kegiatan ekstrakurikuler mampu meningkatkan kesadaran dan sikap peduli lingkungan, yang berarti menanamkan pendidikan karakter sehingga pada peserta didik tentang peduli lingkungan sebagai sekolah berwawasan lingkungan.

\section{Kerjasama dengan Berbagai Pihak}

Sekolah menjalin kerjasama atau kemitraan dengan berbagai pihak seperti orang tua siswa, masyarakat, instansi pemerintah, swasta, media, atau sekolah lain dalam pelaksanaan mengembangkan perilaku peduli lingkungan.

"Melaksanakan kerja bakti satu kali dalam seminggu dan bekerja sama dengan masyarakat yang bermukim di sekitar sekolah". (Hasliah, 15 Agustus 2018, SD Pertiwi).

Hasil wawancara yang dilakukan bersama guru dalam meningkatkan kreativitas dan inovasi membantu mengembangkan wawasan eduktif tentang lingkungan yang diaplikasikan sehingga melahirkan gagasan, proses, metode dan produk baru yang efektif dan bersifat imajinatif dan estetis. Sebagai dampak positif dari kegiatan daur ulang, penyuluhan lingkungan karya seni, hemat energi, dan energi alternatif.

\section{PENGELOLAAN SARANA PENDUKUNG RAMAH LINGKUNGAN}

Kelengkapan Sarana dan Prasarana

Kelengkapan sarana dan prasarana ramah lingkungan yang ada di sekolah seperti air bersih, penyediaan tempat sampah, komposter, pembuangan tinja, drainase, ruang terbuka hijau.

"Sarana dan prasarana seperti air bersih, tempat sampah pembuangan tinja, komposter, drainase dan ruang terbuka hijau sudah ada". (Hasliah, 15 Agustus 2018, SD Pertiwi). 
Untuk menjadi tempat pembelajaran yang baik bagi warga sekolah yang berwawasan lingkungan maka perlu didukung dengan kelengkapan sarana dan prasarana yang ramah lingkungan (Sitisyarah, dkk, 2017). Berdasarkan hasil wawancara kelengkapan sarana dan prasarana telah terpenuhi dengan baik, seperti air bersih, tempat sampah, pembuangan tinja, komposter, drainase, dan ruang terbuka hijau.

\section{Pemeliharaan Sarana dan Prasarana} sekolah.

Sistem pembagian tugas kepada warga sekolah dalam pemeliharaan sarana dan prasarana di

"Tiap siswa dan guru memiliki tugas membersihkan pada masing-masing sarana dan prasarana". (Hasliah, 15 Agustus 2018, SD Pertiwi).

Berdasarkan hasil wawancara yang dilakukan di SD Pertiwi, pemeliharaan sarana dan prasarana melalui sistem pembagian tugas yang dilakukan oleh siswa/siswi beserta guru. Dalam mewujudkan sekolah peduli dan berbudaya lingkungan sarana dan prasarana yang mencerminkan upaya pemeliharaan lingkungan hidup yaitu melalui peningkatan kualitas pengelolaan lingkungan di dalam dan di luar Kawasan sekolah.

\section{Pemanfaataan Listrik, Air, dan ATK}

Cara mendidik semua warga sekolah untuk memanfaatkan listrik, air dan ATK secara efisien dan ramah lingkungan.

"Warga sekolah diimbau untuk memanfaatkan listrik, air dan ATK secara bijak". (Hasliah, 15 Agustus 2018, SD Pertiwi).

Manajemen sekolah menerapkan keberhasilan dan pengelolaan, termasuk dalam pemanfaatan listrik, air, dan ATK salah satunya dengan pemanfaatan listrik, air dan ATK secara bijak. Hal tersebut dilakukan mewujudkan sekolah yang peduli akan budaya lingkungan.

\section{Pelayanan Kantin Sehat dan Ramah Lingkungan}

Kebijakan sekolah dalam meningkatkan kualitas kantin sehat dan ramah lingkungan.

"Kantin diberi himbauan untuk tidak menjual makanan berpengawet, tidak menggunakan zat pewarna, dan lain-lain serta menggunakan celemek ketika memasak". (Hasliah, 15 Agustus 2018, SD Pertiwi).

Sekolah adiwiyata adalah sekolah yang dinilai telah berhasil dalam melaksanakan pendidikan lingkungan hidup (Landryani, 2015). Salah satu persyaratan yaitu peningkatan kualitas pelayanan makanan, seperti kantin sekolah yang bersih dan makanan yang sehat. Pada SD Pertiwi diberlakukan himbauan untuk tidak menjual makanan pengawet, zat pwarna dan menggunakan celemek ketika memasak, pada dasarnya himbauan tersebut akan lebih efisien bila dilakukan aksi pengecekan dan pengontrolan langsung oleh pihak sekolah.

\section{KESIMPULAN}

Hasil Pelaksanaan Program Adiwiyata di SD Pertiwi yaitu: 1) Kebijakan Berwawasan Lingkungan meliputi budaya peduli lingkungan dengan pengembangan kreativitas berfikir siswa dalam menyelesaikan masalah lingkungan sekolah. Budaya peduli lingkungan juga berguna dalam menghasilkan lingkungan sekolah ynag hijau sehat dan nyaman, serta kebijakan sekolah didukung dengan anggaran sekolah untuk penyediaan sarana dan prasarana lingkungan; 2) Pelaksanaan Kurikulum Berbasis Lingkungan meliputi sistem pembelajaran lingkungan dilakukan dengan mengintegrasikan mata pelajaran dengan materi pengetahuan lingkungan seperti pemilahan sampah organik dan non organik serta pemeliharaan tanaman akan tetapi tidak semua guru mampu mengintegrasikan pendidikan lingkungan ke semua mata pelajaran; 3) Kegiatan Lingkungan Berbasis Partisipatif meliputi partisipasi aktif unsur sekolah didukung dengan pengetahuan terhadap adanya program Adiwiyata walaupun masih terdapat siswa yang tidak peham dengan program tersebut, partisipasi tersebut nampak pada pemeliharaan kebersihan kelas dan lingkungan sekolah; 4) Pengelolaan Sarana Pendukung Ramah Lingkungan meliputi pengelolaan sarana dan prasarana sekolah yaitu pada 
pemeliharaan kelas, pemanfaatan listrik, air dan ATK, serta pelayanan kantin sehat dan ramah lingkungan.

\section{Referensi}

Dwi Riskina, M.E.I.R.I.S.A., 2019. Studi Deskriptif Tentang Sikap Peduli Lingkungan Melalui Program Sekolah Adiwiyata di SMAN 2 Pamekasan. Kajian Moral dan Kewarganegaraan, 7(1).

Halimatussakdiah, 2018. Sikap Keteladanan Guru Dalam Meningkatkan Kepribadian Siswa Di Mis Madinatussalam Kecamatan Percut Sei Tuan Kabupaten Deli Serdang. Skripsi, tidak dipublikasi. Universitas Islam Negeri. Medan

Hamzah Syukri. 2013. Pendidikan Lingkungan. Bandung: Refika Aditama

Landriany, e., 2015. Implementasi kebijakan adiwiyata dalam upaya mewujudkan pendidikan lingkungan hidup pada sekolah menengah umum (sma) kota malang (doctoral dissertation, university of muhammadiyah malang).

Muhammad Amin Mangara, 2015. Pencegahan Pencemaran Laut. CV. Sah Media, Makassar.

Pertiwi, N., 2015. Integrasi Pendidikan Lingkungan Hidup Dalam Kurikulum Pendidikan Teknologi Kejuruan. proceedingfptk, 439.

Satya Laksana, 2017. Partisipasi Siswa Dalam Implementasi PLH (Pendidikan Lingkungan Hidup) di SMPN 7 Yogyakarta. Skripsi, Universitas Negeri Yogyakarta.

Sitisyarah, K. and Mustika, R., 2017. Penerapan Program Adiwiyata di SMP Negeri 13 Palembang. JMKSP (Jurnal Manajemen, Kepemimpinan, dan Supervisi Pendidikan), 2(1). 